sciendo DOI: 10.2478/linpo-2018-0013

\title{
Restructuring of the Iranian tense/aspect/mood system
}

\author{
Vit Bubenik $^{1}$ \& Leila Ziamajidi $^{2}$ \\ ${ }^{1}$ Memorial University of Newfoundland, St. John's \\ ${ }^{2}$ University of al-Zahra, Tehran \\ e-mail: vbubenik@mun.ca, lziamajidi@mun.ca
}

\begin{abstract}
Vit Bubenik \& Leila Ziamajidi. Restructuring of the Iranian Tense/Aspect/Mood System. The Poznań Society for the Advancement of Arts and Sciences, PL ISSN 0079-4740, pp. 73-98

The purpose of this paper is to outline the fundamental grammaticalization and degrammat(icalizat)ion processes observable in the restructuring of the tense/aspect/mood systems of the West Iranian languages during their historical development. Their core aspectual systems will be presented as consisting of three categories: Imperfective, Perfective and Perfect.

Special attention will be paid to the rise of the analytic Perfect in Middle Persian and its further development in Early New Persian and other West Iranian languages. It will be shown that the degrammation of the copula played a significant role in the formation of compound temporal (Perfect, Pluperfect) and modal categories (Evidential, Conjectural) in New Persian, Kurdish, Balochi and Tajik. The Evidential mode of New Persian is based on the analytic Perfect rafte ast 'he is gone' and it is found in all the three aspectual categories (Imperfective, Perfective and Perfect) and both voices. It is usually claimed that it developed in the Iranian languages probably under Turkic influence. We intend to address the contentious issue of syntactic borrowing in terms of language contact in another paper.
\end{abstract}

Keywords: aspectual system, imperfective, perfective, perfect, copula, analytic vs. synthetic morphology, grammaticalization, degrammati(calizati)on, evidential mode

\section{Introduction}

The core aspectual system of the New West Iranian languages, exemplified by New Persian in Table 1, can be represented as consisting of three aspectual categories Imperfective, Perfective and Perfect (or Retrospective) and a binary distinction of tense (Past vs. Non-Past). 
Table 1: The New Persian core Tense/Aspect/Mood system

\begin{tabular}{llll}
\hline & Imperfective & Perfective & Perfect \\
[-Past] & mi-kon-am & be-konam & karde-am \\
& 'I do' & 'I may do' & 'I have done' \\
[+Past] & mi-kard-am & kard-am & karde bude am \\
& 'je faisais' (Imperfect) & 'I did' & 'I have done \\
\hline
\end{tabular}

Note: Given the absence of the inflectional Imperfect in English we will gloss the Iranian Imperfect in French which possesses its equivalent.

This 'triad' of aspectual categories (Imperfective, Perfective, Perfect) continues the system of Old Iranian documented by Old (Cuneiform) Persian and Gathic texts (Reichelt 1909/1978, Skjärvø 2009). As in Old Indo-Aryan they are dichotomized by the binary distinction of tense Imperfective (Present and Imperfect), Perfective (Injunctive and Aorist) and Perfect (Perfect and Pluperfect) with the Imperfect, Aorist and Pluperfect being marked categories [+Past]

\section{Aspectual system of Iranian languages}

\subsection{On the status of the perfective kard 'he did'}

Before we proceed some observations on terminological issues found in the works of prominent Iranists are in order. Our terminology is in keeping with Lazard (1989) and Windfuhr (1987, 2009). Lazard (1989: 273) labels the imperfective categories by the term 'durative' and the past perfective raft 'he went' by the temporal-aspectual term 'Aoriste Passé'; the phrasal perfect categories are labeled Perfect Present and Perfect Past. Windfuhr (2009: 24-25) analyzes the Early Old Iranian system, its Middle Persian and 'Pre-Modern' descendants in terms of "triple aspect which intersects with binary tense parameter". The central form of the core aspectual system is the "perfective Aorist".

In Gathic and Old Persian documents there are two types of the Aorist: athematic type with personal suffixes attached to the root (e.g. $a-d \bar{a}$ 'he created' cf. Skt á-dhā- $t$ ) and the sigmatic type (mediopassive $a$-dar-š-iy 'I occupied', cf. Skt á-dik-ș-i 'I showed'). At the end of the Old Iranian period both forms were lost and the finite perfective category (Aorist) was replaced by the perfective participle in -tá (referred to usually as the past participle, abbreviated PP). In Early New Persian this form has been incorporated into the system of finite forms and the new perfective participle had to be recreated by the grammaticalized adjectival suffix *-aka $>-a g>-\mathrm{a}>-e$ (kard-e). The earlier form $-a g$ is documented in the Balochi Perfect kapt-a(g)-un 'I have fallen' built on the perfective participle kapt-un 'I fell' (see Jahani \& Korn 2009: 659). The suffix $-a g$ is also seen in the 'second' past participle of Tajik built on the past participle in $-a$ : $̌ u d-a$ '(having) become' > šud-agī 'having become', girift-a '(having been) taken' > girift-agi 'having (been) taken' (see Windfuhr \& Perry 2009: 449). Synchronically, the participial 
source of this basic form is more obvious in those Iranian languages which have not lost the distinction of gender and possess the ergative construction. There is no gender marking in New Persian pronouns ( $u$ 'he/she', $u=r \bar{a}$ 'him/her') while Pashto (East Iranian) distinguishes their gender in direct (day 'he', $d \bar{a}$ 'she') and oblique forms ( $d \partial$ and $d e$ ) but not in possessive clitics (ye). The basic form lid-ál (corresponding to New Persian did 'saw' has to be marked for gender in the Imperfective, Perfective and Perfect. Contrast Pashto (in 1) with New Persian in (2):
(1) day=ye lid-á 'he/she saw him'
he.(s)he-OBL see.PP-M
dā=ye lid-ól-a 'he/she saw her'
she.(s)he-OBLsee.PP+F

(2) $\mathrm{u}=\mathrm{ra} \quad$ did 'he/she saw $\underline{\text { him }}$ ' 'he/she saw $\underline{\text { her' }}$

he/she (s)he=ACC see.PP

In a sense the basic form in Pashto is 'semi-finite' but it should be emphasized that in the $1^{\text {st }}$ and the $2^{\text {nd }}$ Person it takes the personal suffixes in the same fashion as New Persian does:

$\begin{array}{lll}\text { (3) Pashto } & \text { New Persian } \\ \text { wó-kṛ-əm } & \text { kard-am 'I did' } \\ \text { wó-kṛ-e } & \text { kard-1̄ } & \text { 'you did' } \\ \text { wó-kər (wó-kəy) 'he did' } & \text { kard } & \text { 'he/she did' } \\ \text { wó-kṛ-a (wó-kṛ-əl-a) 'she did' } & & \end{array}$

\subsection{Changes in the aspectual system of Old Iranian}

\subsubsection{The loss of the Old Iranian finite forms}

During the Early Middle Iranian period the Old Iranian finite forms (Imperfect, Aorist, Perfect) were ultimately lost and the whole system was rebuilt on the basis of the passive perfective participle (PP) kar-t-am (Neuter)'done'. The Old Persian finite Aorist form $a-k u-m \bar{a}$ 'we did' (corresponding to Vedic $a-k r-m a$ 'we did') was replaced by the possessive/passive construction ahmākam kart-am, lit. we-GEN done-NEUT '(it was) done of/ by us'. As it happens, the $1^{\text {st }} \mathrm{Sg}$ form is not documented in Old Persian (its counterpart in Vedic is a-kar-am 'I did'), but the possessive/passive construction with the singular genitive form manā kart-am '(it was) done by me' is used in Iranian linguistics. The realignment of the erstwhile 'be'-passive through the Possessive/Passive-to-Ergative shift 'done of/by me' > 'I did' can be portrayed as a consequence of the loss of the synthetic morphology expressing the notion of perfectivity. The resulting Middle Persian is sketched in Table 2. 
Table 2: Middle Persian Tense/Aspect system

\begin{tabular}{llll}
\hline \multirow{2}{*}[-\text{Past}]{} & IMPERFECTIVE & PERFECTIVE & PERFECT \\
& kun-am/ēm & (AORIST & kard(a) ham \\
& & was lost $)$ & 'I have done' \\
{$[+$ Past $]$} & (IMPERFECT & $\mathrm{u}=\mathrm{m}$ kard & kard(a) būd ham \\
& was lost $)$ & 'and I did' & 'I had done' \\
\hline
\end{tabular}

It is important to realize that during the intervening period of several centuries between the Late OI and Early MI period the rich participial system of Old Iranian (of four active and four medio-passive participles) was also gradually eroded and New Persian ended up with only three basic participles (in aspectual terms): imperfective active participle kon-ān in -ān $(<$ OI -ant), perfective participle kard $(<$ the OI passive perfect participle kart-am $<* k$-tam 'done'), and innovative future participle (or gerundive) derived by stressed $-i$ from the infinitive: raft-an-i 'about to go', did-an-i 'worth seeing', goft-an-i 'that must/can be said'. While these formations are lexicalized in New Persian and the construction with the auxiliary bud 'be' is 'marginal', in Tajik it is used extensively in expressions of intention: man raft-an-ī hast-am 'I am going, I am off' (Windfuher \& Perry 2009:449-450). Regarding the innovative 'second' past participle of Tajik in $-a g-\vec{\imath}$ see 6.3 .

Table 3: Old Iranian participial system

\begin{tabular}{lllll}
\hline & IPFV & PFV & PERF & FUT \\
Active & -ant & -vah & -šy-ant & \\
Medio-passive & -mna & -nhāna & -āna & -hya-māna \\
Passive & & & -ta/-na & -ata/-Ova (Gerundive) \\
\hline
\end{tabular}

The Old Iranian participial system - in so far as the mediopassive morphology was preserved - resembled very much that of other Ancient IE languages (Sanskrit and Ancient Greek). Its salient feature is the existence of the aspectual opposition of the imperfective (IPFV) and Perfect (PERF) in the active and mediopassive diathesis (active IPFV in -ant vs. mediopassive IPFV in -mna, and active PERF in -vah vs. mediopassive PERF in -āna). The 'empty slot' for the perfective (PFV) active category (participle of the Aorist) results from the quintessential Iranian phonological process of fricative weakening $(s>h)$ which inhibited the rise of salient sigmatic categories (both Aorist and Future) with $-s$ - in the intervocalic position (unlike in Sanskrit and Greek). In later development connected with the rise of the ergative construction the role of the perfective category was taken over by the formations based on the passive perfect participle in $-t a$. 


\subsubsection{The rise of analytic aspectual formations}

It would be erroneous to think of the development from Old Iranian to Middle Persian state of affairs as exemplifying a 'cataclysmic' change from an earlier synthetic wordbased morphology to later configurational morpho-syntax exploiting auxiliaries. The participles continued to play an important role in the formation of subordinate clauses (expressed by the absolute constructions with the genitive, locative and ablative case of the infinitive). The morphosyntax of the Late OI period is accessible to us by the evidence of Younger Avestan texts where in addition to inherited OI word-based morphology we witness the rise of analytic formations heralding a later state of affairs. They helped to express several aspectual nuances, such as the notion of duration in the present, past and future time zones; and in addition there were also periphrastic formations of the mediopassive and passive Perfect.

The notion of duration in the present and in the past was expressed by combining the copula (and other lexical verbs such $\bar{a} h$ - 'sit' and stä- 'stand') with the present (imperfective active) participle (examples in Reichelt 1909/1978: 329-330; Jackson 1892/1968: 199-200):

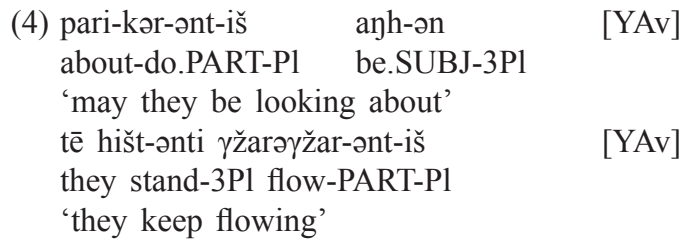

It is remarkable that the innovative Old Iranian 'progressive' construction survived in certain contemporary dialects (Zazaki, Northern Tati, Eastern Gilaki and Mazandarani) and small communities around Semnan (see Windfuhr 2009: 22). Here the progressive construction featuring the participial suffix *-ant was grammaticalized as the simple present tense (instantiating grammaticalization Aspect $>$ Tense): Sangesari (near Semnan): va pors-in/-an, pors-end-a, pors-end-e 'I demand', etc. (Lecoq 1989: 310) versus New Persian mi-pors-am, pors-i, pors-ad). In Middle Persian the notion of duration in the past was expressed by means of the preterit in combination with the adverb hamēw 'always' ( $>$ hamēe) as in wāng hamē kard 'he was crying' [Ardā Wirāz Nāmag 25.13]. In later development the Early New Persian form hame was reduced to mi- which was ultimately cliticized as an imperfective marker to both the present and the past stem ( $m i=k o n$ - and $m i=k a r d-$ ). In New Persian the innovative progressive aspect is formed analytically by means of the grammaticalized forms of the lexical verb dāštan 'have' in the present and the past: $d \bar{a} r$-am $m i=k o n$-am 'I am doing' and $d \bar{a} \check{s} t$-am mi=kard-am 'I was doing').

\subsubsection{The future tense in Old Iranian}

A propos the Future, Old Persian and Gathic possesses examples of the sigmatic Future (vax-šy-ä 'I will speak') inherited from Proto-Indo-Iranian. The formation of the 
active future participle corresponds to that of Sanskrit: YAv $b \bar{u}-\bar{s} y$-ant 'who is about to be' (Skt bhav-isy-ant). With the vocalic roots the marker $-s$ was weakened as in the imperfective mediopassive uz-dā-hya-mna 'to be given out' (cf. Sanskrit dā-sya-māna give. FUT-MED/PASS 'to be given') in Vīspered 9.3 (quoted after Reichelt 1909/1978: 329):

(5) yōi hənti homa ... uz-dā-ta ... uz-dā-hya-mna [Vīspered 9.3]

which.Pl are homa-sticks out-give.PP out-give.FUT-MED/PASS

'the homa-sticks which are set out and which have to be set out'

Instead of the active sigmatic Future (Sanskrit $d \bar{a}-s y \bar{a}-m i$ 'I will give') Gathic uses the Injunctive, i.e. augmentless Aorist (Reichelt 1909/1978: 321).

\subsubsection{The medio-passive diathesis in Old Indo-Iranian}

Old Iranian inherited a rich system of mediopassive forms from Proto-Indo-Iranian. As far as the passive forms are concerned, in the imperfective aspect there are mediopassive forms which could be used in the selfbenefactive meaning or (especially in the third person) in the passive meaning:

(6) Present: bar-e 'I carry for myself' [Gathic]

bar-ate 'he carries for himself' 'it is (being) carried'

Imperfect: bar-e 'I carried for myself'

bar-ata 'he carried for himself' 'it was being carried'

The corresponding Sanskrit forms (based on various verbs) are presented in (7):

(7) Present: bhar-e 'I carry for myself' [Sanskrit]

bhar-ate 'he carries for himself' 'it is (being) carried'

Imperfect: $a$-bhar-e 'I carried for myself'

a-bhar-ata 'he carried for himself' 'it was being carried'

In Indo-Aryan in the imperfective aspect there are also unambiguous passive forms (based on the ablauted root plus the passive marker $-y$; the personal suffixes are those of the mediopassive in 6 and 7) which in IA are used in all persons: bhri-ye 'I am carried', bhri-ya-se 'you are carried', bhri-ya-te 's/he is carried'). In Old Iranian this formation is practically limited to the $3^{\text {rd }}$ Person: bar-ye-nte 'they are carried' with no ablaut in the root (vs. OIA bhri-ya-nte) or even kir-ye-ti 'he is made' with the active suffixes (vs. OIA kri-ya-te), see Reichelt 1909/1978: 298-299).

In the perfective aspect (Aorist) there are no examples of active or mediopassive participles paralleling the asigmatic Aorist of Vedic $(k r-a n t, k r-\bar{a} n a)$. In both Vedic and Gathic there is a remarkable finite form of the passive Aorist in $-i$ : $a-s \operatorname{s} \bar{a} v-i$ 'it was heard', Gathic srā v-ī. In the passive Perfect there are analytic formations combining the copula with the mediopassive Perfect participle in -āna: 
(8) yōi hənti homa ... hunv-āna (Reichelt 1909/1978: 329)

which.Pl are homa-sticks press.MED/PASS

'the homa-sticks which are being pressed' (passive meaning)

In Middle Persian (Pahlavi) the notion of duration in the past could be expressed analytically by the perfective participle in combination with the adverb $\operatorname{hame}(w)$ 'always, continuously':

(9) ka-š

gar bālāy rōšnīh az-iš

who=he.3Sg mountain high brightness from=he.3Sg

hamē waxšīd

[Ardā Wirāz Nāmag 16.6]

continuously radiate-PP

'from whom the brightness as high as a mountain continuously radiated'

\section{Imperfective categories (Present and Imperfect)}

\subsection{The Old Iranian Imperfect}

The Old Iranian Imperfect displayed secondary suffixes; in addition, the augment inherited from Proto-Indo-Iranian - appears in Old Persian but not (so consistently) in Gathic; those two varieties are contrasted in (10):

\section{Present and Imperfect in Old Iranian}

$$
\begin{array}{ll}
\text { Present } & \text { Imperfect } \\
\text { 'he does' } & \text { 'he did' }
\end{array}
$$

Gathic kr-nao-ti 'he does' kr-nao-ţ 'he did'

Old Persian ku-nau-tiy a-ku-nau-š

To judge by Middle Persian inscriptions the augment survived in certain forms such the passive Imperfect:

\begin{tabular}{|c|c|c|}
\hline Passive & $\begin{array}{l}\text { Present } \\
\text { 'it is done' }\end{array}$ & $\begin{array}{l}\text { Imperfect } \\
\text { 'it was done' }\end{array}$ \\
\hline Middle Persian & kun-īh-ēd & a-kir-īh \\
\hline & kir-ēd & a-kir-īh-ist (Parthian) \\
\hline
\end{tabular}

(11) Passive Imperfect

Several examples of augmented forms are available in the inscriptions of one chief magus Kirdēr (Henning 1958: 101-102), where there are examples which correspond exactly to the Old Persian Imperfect a-bariya 'was brought, a-kariya 'was done' (cf. Sanskrit mediopassive Imperfect $a$-bhri-ya-ta, $a-k r i-y a-t a)$. There are also augmented forms of the passive Imperfect with different suffixes (-ih or -iy ) as in (12):
(12)

$\begin{array}{lllll}\mathrm{u}=\mathrm{m} & \text { a-kir-īh } & \text { nām } & \text { kirdēr } & \text { [Middle Persian] } \\ \text { and=I-OBL } & \text { make.PASS/IMPF-3/Sg } & \text { name } & \text { Kirdēr }\end{array}$




\subsection{The present tense in Middle Persian}

In Middle Persian the suffixes of the present tense are practically identical with those of the copula $h$ - 'be' (data in Skjärvø 2009: 216-219):

(13) Middle Persian present indicative and the copula

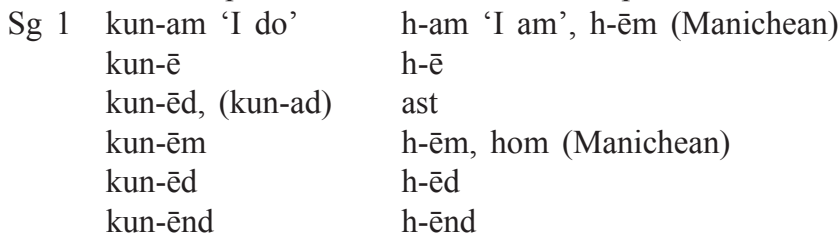

It could be that several of them continue the Old Iranian suffixes (cf. Gathic bar-ämi 'I carry', MP kun-am, Parthian kun-ām/-am; Gathic 1 ${ }^{\text {st }} \mathrm{Pl}$ bar-āmahi, Parthian kun-ām).

\subsection{The Imperfect in New Iranian}

With the loss of the Old Iranian inflectional Imperfect (in 10) a number of prefixes/ particles started being used with the PP form to recreate the category of imperfectivity. Windfuhr (1989: 256) suggested that they can be projected back to the adverbial phrase *hama-aiva-da 'same time' to account for the considerable variety of imperfective/indicative markers in the West Iranian languages: New Persian $m i-(<$ Early New Persian hame $<$ Middle Persian hamēw), $a=$ in Central Kurdish (Sorani), $d a=$ in Mokri and $d i=$ in Kurmanji. In Sorani the particle $a=$ is a prefix with intransitive verbs (a-hāt-im 'je venais', $a-h \bar{a} t-\bar{l}$ 'tu venais', etc.), which with transitive verbs hosts the possessive suffixes ( $a=m$ vut 'je voyais', $a=t$ vut 'tu voyais', etc.

\section{Restoration of the category of perfectivity}

\subsection{Restoration of perfectivity in Pashto}

In semantics of the tense-aspect-mood the central issue of this diachronic process was the restoration of the aspectual triad of Old Iranian in terms of innovative analytic morphology. Pashto (East Iranian) did it successfully by introducing a new perfectivity marker wá; as is shown in (14) its combination with the modal particle $b a$ in the Present marked a perfective Future (data in Robson and Tegey 2009: 721-772):

\begin{tabular}{|c|c|c|c|}
\hline & Imperfective & & Perfective \\
\hline $\begin{array}{l}\text { Preser } \\
\text { Past }\end{array}$ & $\begin{array}{l}\text { raség-e 'he arrives' } \\
\text { raséd-e 'il arrivait' }\end{array}$ & (Imperfect) & $\begin{array}{l}\text { ba wə-raség-e 'he will arive' } \\
\text { wó-rased-e 'he arrived' }\end{array}$ \\
\hline
\end{tabular}

In West Iranian langauges (as in Kurdish and Balochi) perfectivity is unmarked, or rather the finitized PP form is aspectually ambiguous: 
(15) Balochi

Present kap-it 'he falls'

Past kapt 'he fell, il tombait'
Kurdish

yē-t 'he comes'

hā-t 'he came, il venait'

This 'deficiency' in the aspectual system is offset by the existence of various periphrastic formations. In Balochi several dialects employ the infinitive in the oblique form with the copula:

(16) man guš-ag-ā un [Jahani \& Korn 2009: 675]

I say.INF-OBL be.1Sg

'I am saying' (West Balochi)

In Pakistani South West Balochi there is the 'canonic' construction based on the present participle:

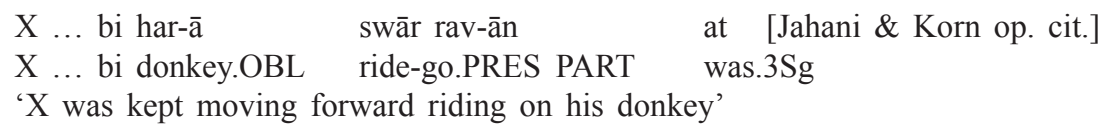

Here apparently the contact with Urdu was instrumental in its formation.

\subsection{Markedness values of the three aspectual categories}

It should be observed that the markedness values in New Persian changed as a result of its restructuring from the earlier Middle Persian ergative typology (with the marked perfective and unmarked imperfective) to the accusative typology of New Persian with the imperfective category unmarked.

(18) Markedness values of the three categories in Middle and New Persian

Middle Persian

Imperfective $\mathrm{U}$

Perfective $\quad$ M (ergative)

Perfect MM
New Persian

$\mathrm{M}$

$\mathrm{M}$

$\mathrm{MM}$

$\begin{array}{llll}\text { Imperfective } & \overline{\mathrm{o}} \text { kun-ēd } & \text { 'he does' } & >\overline{\mathrm{u}} \text { mi-kon-ad 'he does' } \\ \text { Perfective } & \mathrm{u}=\mathrm{s}(\text { ERG) kard } & \text { 'and he did' } & >\overline{\mathrm{u}} \text { kard 'he did' } \\ \text { Perfect } & \overline{\mathrm{o}} \text { kard(a) ast } & \text { 'he has done' } & >\overline{\mathrm{u}} \text { kard-e ast 'he has done' }\end{array}$

The pivotal event in the history of Persian was the rise of the analytic Imperfect by the grammaticaliztion of the adverb hame $(w)$ plus the PP. Intermediate forms hame $>$ (ha) $m \bar{e}>m i$ are documented in Early New Persian where they became the marker of the imperfective aspect (2.3):

(19) Middle Persain $u=m$ hamè (w) kard 'and of me always done' > ENP man hame kardam > NP mi-kard-am 'I did' (corresponding to the French Imperfect je faisais) 
(20) Early New Persian core aspectual system and its markedness values (raft-an 'arrive)

IPFV

[-Past] mē rav-ad

PFV

PERF

$[+$ Past $]$ mē raft

$\mathrm{M}$

be-rav-ad (Subj)

raft-a ast

be-raft (Aorist)

raft-a būd

$\mathrm{M}$

MM

By way of contrast in the Pashto system the imperfective category is unmarked (raséd$a l$ 'arrive' and the perfective category is marked by the prefix wá- (raséd-al 'arrive', after Šafeev 1964: 37):

$\begin{array}{llll}(21) & \text { IPFV } & \text { PFV } & \text { PERF } \\ \text { [-Past] } & \text { raség-e } & \text { wó-raseg-e (Subj) } & \text { rased-ól-ay day } \\ \text { [+Past] } & \text { raséd-e } & \text { wó-rased-e } & \text { rased-ól-ay wə̀ } \\ & \text { U } & \text { M } & \text { MM }\end{array}$

\subsection{Innovative future tense}

Major differences appear in the formation of the Future which started as the modal perfective category. In Old Iranian the injunctive (= augmentless Aorist) functioned as the future tense. In New Persian the slot of the perfective/Present is occupied by the subjunctive be-rav-ad 'may he go' corresponding to Pashto wá-raseg-e (Subj). Using the same modal particle $b a$ in conjunction with its perfectivizing prefix wá Pashto distinguishes imperfective and perfective Future: ba raség-e 'he will be stopping' (Imperfective) versus ba wá-raseg-e 'he will stop' (Perfective). New Persian grammaticalized the lexical verb $x^{w} \bar{a} s t$-an 'to want' in combination with the short infinitive ( $x \bar{a} h$-am kard 'I will do') for this purpose; in addition in colloquial Persian - as in Kurdish - the present indicative can be used to locate the event in the future time zone. With verbs of motion the imperfective form mi-rav-ad can function as the imperfective future 'he will be arriving' versus perfective $x \bar{a} h$-ad raft 'he will arrive'. This aspectual contrast in the future time zone is shown in (22):

$$
\text { IPFV PFV }
$$

Pashto ba raség-e ba wá-raseg-e

New Persian mi-rav-ad xāh-ad raft

\section{The rise of the analytic Perfect in Iranian}

\subsection{Recreation of the old aspectual categories on an analytic basis}

As was shown in Table 2 the Imperfect and Aorist were lost and the old aspectual categories (Aorist and Perfect) were recreated on an analytic basis by combining the passive participle with the verbum existentiae. The ergative construction had already appeared during the Old Iranian period as a 'pseudo-possessive' construction manā kartam lit. of-me done 'I did' in (23): 
(23)

\begin{tabular}{|c|c|c|}
\hline $\mathrm{ma}$ & $\begin{array}{l}\text { tya manā } \\
\text { which } \text { I.GEN }\end{array}$ & $\begin{array}{l}\text { kartam } \\
\text { do.PP }\end{array}$ \\
\hline & $\begin{array}{l}\text { ya } \theta \bar{a} \text { xšāya } \theta i y a \\
\text { when king }\end{array}$ & $\begin{array}{l}\text { abavam (Kent } 1953 \text { [DB I, 28-29]) } \\
\text { become.IMPF-1Sg }\end{array}$ \\
\hline
\end{tabular}

'This (is) that (which) was done by me after (I) became king'

This passive construction (manā kartam lit. 'of me done') became an alternative way of expressing past completive events instead of the active Aorist; i.e. the speakers of Old

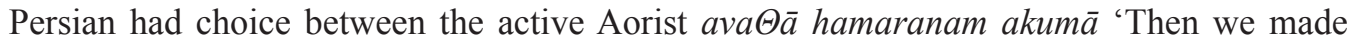

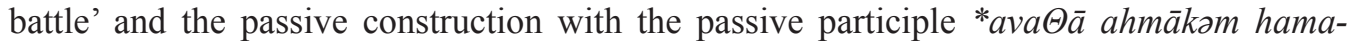
ranam kartam of-us battle done 'Then battle was made by us'. With the attrition and an ultimate complete loss of the finite forms the construction with the PP participle started being interpreted ergatively as 'Then we made battle'. It is important to realize that in Old Iranian there also were finite passive counterparts to it (Gathic srā $\bar{\imath}$ 'he was heard', Young Avestan jani 'he was killed') so at a certain time period there was choice in expressing the past completed action in the passive by the later finite form jani ( $3^{\text {rd }} \mathrm{Sg}$ ) 'he was killed' or the non-finite construction bardiya avaja-ta (PP) 'Smerdis [was/had been] slain'.

The neuter suffix marking on the PP form kart-am 'done' (Neuter) was lost leaving only the bare form kard; furthermore, the conjunction uta 'and' which could host the pronominal agent was reduced to $u$ 'and'. An example in (26) shows the Old/Middle Persian incipient ergative construction $u t \bar{a}=$ maiy kartam 'and it was done by me':

$\begin{array}{lllll}\text { utā=maiy anijasçiy } & \text { vasiy } & \text { astiy } & \text { kartam ([DB IV.46] } & \text { Kent 1953) } \\ \text { and=I.GEN else } & \text { much } & \text { is } & \text { done } & \\ \text { 'and much else was done by me' } & & \end{array}$

During the Middle Persian period the construction $u t \bar{a}=$ maiy kartam was reduced to $u=m$ kard '(and) I did'. Subsequently, the construction $u=m$ kard 'I did' ( $u=t$ kard 'you did', $u=\check{s}$ kard 'he did') was restructured as an ergative construction by being moved into the erstwhile domain of the active perfective category (Aorist).

\subsection{Evidence of the extinct Middle Iranian languages}

At this point we want to mention the state of affairs in the two extinct Middle Iranian languages (Sogdian and Khwarezmian) which replaced the monolectal Perfect of Old Iranian by the periphrastic construction based on the past stem in $-a k a$ with the auxiliary $\delta \bar{a} r$ - 'hold' (data in Yoshida 2009: 279-335 and Durkin-Meisterernst 2009: 336-376). Its lexical ancestral meaning is documend in Avestan $d i-\delta \bar{a} r$ - 'grasp' and Old Persian dar- 'hold fast, live in/at' (OP dār-ay-ämiy 'I possess', Avestan $v \bar{\imath}-\delta \bar{a} r$-ay-eti 'he supports').

$\begin{array}{ll}\text { wēt } \delta \text { ār-ām } & \text { 'I have seen' [Sogdian] } \\ \text { see.PP hold-1Sg } & \\ \text { wēt } \delta \text { ār-t } & \text { 'he has seen' }\end{array}$


wēt $\delta$ ār-ant 'they have seen'

ak-āmi 'I do' [Khwarezmian]

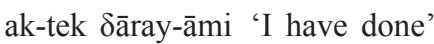

In some contemporary North Western Iranian languages several varieties of the 'have' Perfect (formed by the auxiliary $d \bar{a} r$ - 'hold') are found in the Caspian dialects (Gharib 2005; Kalbāsi 2004). Gharib provides examples from the Sangečāl dialect where there is an important difference between the Perfects of transitive verbs (marked by the particle $b a-)$ and the intransitive Perfects: ba-xərd-dār-mə 'I have eaten' versus burd dār-mə 'I have gone'. The Pluperfect counterparts are formed by the auxiliary in the past form: burd dāšt-ə-mə 'I had gone'.

In Middle Persian the lexical verb èstād- 'stand' (< Old Iranian stā- 'stand; place') was grammaticalized as an auxiliary of the Perfect. An earlier type of the Perfect featured the PP form finitized by the copula (data in Skjärvø 2009: 219):

Middle Persian Preterit (Perfective) and the Perfect

Preterit šud h-am 'I went' šud est-am 'I have gone'

Pluperfect šud būd h-am 'I had gone' šud estād h-am 'I had gone'

\subsection{The development of the PP form}

An earlier state of affairs before the rise of the innovative PP form displays finitized forms of the PP which are ambiguous between the Perfective (Preterit) and the Perfect. This apparently is the case of Zazaki (where the PP form is marked for gender: $-e(\mathrm{M})$, $-\bar{a}(\mathrm{~F})$ and $-e y(\mathrm{Pl}))$ and certain Preterit and Perfect forms cannot be distinguished (data in Paul 2009: 545-586):

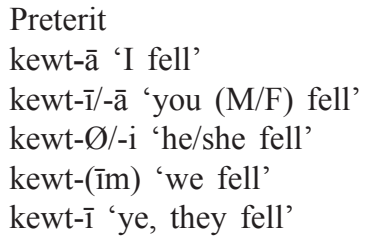

Perfect

kewt-ā 'I have fallen'

[Zazaki]

kewt-ē/-ā 'you (M/F) have fallen'

kewt-o/-ā 'he/she has fallen'

kewt-ē 'we, ye, they have fallen'

The unmarked PP form kewt 'he fell' is used as the masculine form in the $3^{\text {rd }} \mathrm{Sg}$ Preterit and the feminine form is marked with $-i$; their Perfect counterparts show suffixes which are identical with those of the copula est-o 'he is, est $\bar{a}$ 'she is', est- $\bar{e}$ 'they are'

As mentioned in Section 2.1 (examples in 3) the PP form is also marked for gender in Pashto (East Iranian) which forms its Perfect by finitizing the infinitive form in $-a l$ by the copula. The stem of the Perfect is formed by the adjectival suffix -ay: lik-al-ay 'written' (M) lik-al-e 'written' (F). Contrast the formation of the Preterit (Perfective) walik-al-am 'I wrote' with the Perfect lik-al-ay yam 'I have written'. In the Perfect the copula is not cliticized to the participle and it is marked for gender in the $3^{\text {rd }}$ Pers: 
(28)

$\begin{array}{lll}\text { daredál-ay yəm } & \text { 'I have stopped' } & \text { [Pashto] } \\ \text { daredól-ay ye } & \text { 'you have stopped' } \\ \text { dared-ól-ay dəy } & \text { 'he has stopped' } \\ \text { dared-ól-e da } & \text { 'she has stopped' }\end{array}$

\subsection{Further development of the analytic Perfect in West Iranian}

With transitive verbs in late Middle Persian texts the analytic 'be'-Perfect ud man kard ham 'and I have done' is derivationally linked with the passive in exploiting the copula auxiliary in conjunction with the PP form of the main verb. In the context of the demise of ergativity it is observed that in the Perfect ud man kard ham the copula is in the $1^{\text {st }} \mathrm{Sg}$ (lit. of-me done I-am, i.e. 'I am the (one) who has done') and guarantees thus an unambiguous active interpretation of the former passive construction mana kart-am 'done by me' as shown in (29):

$\begin{array}{lllll}\text { ud pas man namāz } & \text { burd } & \text { ham } & \text { ud goft [Ardā Wirāz Nāmag 14.6] } \\ \text { and then I.OBL homage } & \text { bring.PP } & \text { be.1Sg } & \text { and say.PP } \\ \text { 'and I bowed and said' } & & & \end{array}$

In further development the auxiliary $h$ - 'be' in conjunction with the PP form of the main verb became the regular passive: (kard-būd 'it became done' > 'it was done', kard $\bar{e} s t-\bar{e} d$ 'it has been done', kard èstād 'it had been done'). At the end of the MP period the passive construction was again rebuilt, this time by means of the verb šodan as an auxiliary (grammaticalized lexical verb 'to go'). In New Persian Farsi it functions as a full-fledged passive auxiliary (kard-e šod 'it was done').

There is considerable variation in the shape of the innovative perfective participle in West Iranian. The New Persian form kard-e goes back to kard-a < kard-ag (with an adjectival suffix $-a g)$. The suffix $-a g$ is preserved in Balochi kurt-a(g) 'done', kapt-a(g) fallen' and appears in the Perfect and Pluperfect (data in Jahani \& Korn 2009: 665).

(30) Balochi Perfect and Pluperfect of kapt-in 'to fall

Present Preterit Perfect Pluperfect

Sg 1 kap-īn kapt-un kapt-a(g)-un kapt-ag-at-un

2 kap-ay kapt-ay kapt-a(g)-ay kapt-ag-at-ay

3 kap-ît kapt-Ø kapt-a(g)-Ø kapt-ag-at-Ø

It should be mentioned that the suffix $-a g$ in addition to deriving the innovative PP form it derives also the infinitive when added to the present stem (kan-ag 'to do'). The Pluperfect is formed by inserting the 'frozen' (degrammaticalized) form of the copula, at $(<a s t)$, between the past participle and the personal suffixes: kapt-ag-at-un fall.PP-COP1SG 'I had fallen'. By contrast, the New Persian Pluperfect is double finite in fully conjugating the copula: kard-e bud-am do.PP be.P-1Sg 'I had worked', kard-e bud-i be.PP-2Sg 'you had worked', etc. 
In Kurdish Sorani (Sinayi) the perfective participle displays the suffix -ig but in Mokri Sulaymani the PP form displays the suffix $-\bar{u}$. In Gurani the form kard-a is enlarged by - $n$ - (data in Mokri 2003: 229-230):

Sorani (Sinayi)
'I have said'
wut-ig-m-a
wut-ig-t-a
wut-ig-y-a

Mokri
'I have done'
kird-ū-m-a
kird-ū-t-a
kird-ū-y-a

Gurani

'I have done' karda-n-im karda-n-it $\sim$ karda-n-1 karda-n-iš $\sim$ karda-n

In diachronic terms the Kurdish monolectal forms of the Perfect (wut-ig-m- $a$ 'I have said', kird- $\bar{u}-m-a$ 'I have done') are earlier than Farsi analytic formations combining the PP (kard-ag >) kard-e with the copula karde am 'I have done' (from earlier *kard-ag $h$-am). The Gurani forms with possessive clitics ( $\mathrm{N}=i t$ 'your N', N=ǐs 'his/her N', karda$n$-ǐ̌ 'his saying' > 'he has said') hark back to an earlier state of affairs when the ergative construction was formed (cf. Pahlavi $u=\check{s}$ kard '(and) he did'); this is even more obvious in the plural: karda-n-mān 'we have done', karda-n-tān 'ye have done', karda-n-šān 'they have done' (cf. Pahlavi $u=\check{s} \bar{a} n$ kard hēnd '(and) they have done'); the alternative set of suffixes (karda-n-ìm 'we have done', karda-n-inn 'ye/they have done ') features apparently in some instances the cliticized forms of the copula (karda-n-ìm 'we have done', Pahlavi kard=hèm 'we have done'; karda-n-īn 'they have done', Pahlavi kard=hēnd 'they have done').

\section{New Iranian}

\subsection{Early New Persian}

In Middle Persian the 'be'-Perfect was ambiguous between the perfective (Preterit) and perfect reading: šud h-am 'I went' 'have gone' (see Skjärvø (2009: 219). With the demise of the unambiguous 'stand'-Perfect (šud êst-êd 'he has gone') it became necessary to renew the 'be'-Perfect in its perfect reading. The auxiliary $h$ - 'be' continued being used and it was attached to the plain Perfect stem or to the Perfect stem enlarged by $-a$ ( $<$ $-a g$, a derivational adjectival suffix as in Middle Persian). The picture emerging from the analysis of the Early New Persian texts of the $10^{\text {th }}-11^{\text {th }}$ c. by Lenepveu-Hotz (2013: $123-135,212-235)$ is summarized in Table 4.

Table 4: The use of compound forms in Early New Persian Texts $\left(10^{\text {th }}-11^{\text {th }} \mathrm{c}\right.$.)

\begin{tabular}{llll}
\hline Present & kunad & (ha)mē kunad & kard(a) ast \\
Past & kard & (ha)mē kard & kard(a) būd \\
Distant past/Evidential & kard(a) ast & (ha)mē kard(a) ast? & karda būda ast? \\
\hline
\end{tabular}


A significant change is observable in the texts composed in the following centuries (summarized on pp. 235-236). The use of the plain PP (kard) was discontinued and in the texts composed during the $13^{\text {th }}-14^{\text {th }}$ centuries the Perfect is based on the PP enlarged by the suffix $-a$ : kard- $a$ ast 'he has done' and Pluperfect kard-a büd 'he had done'. While Lenepveu-Hotz (2013: 128-130) in her analysis of Early New Persian texts has not observed any semantic difference between the Perfects based on the plain PP (kard ast) and the PP enlarged by -a (kard-a ast), both 'he has done', a significant difference can be observed in Early Judaeo-Persian texts (of $8^{\text {th }}-12^{\text {th }}$ c.) analyzed by Paul (2013). Their importance for the study of the transition from the Middle Persian state of affairs to the Early New Persian lies in their independent development of Early New Persian for several centuries and in their preservation of a number of dialectal features not found in ENP. Of fundamental importance is the fact that several Early Judaeo-Persian texts were located in southwestern Iran, while the ENP texts are predominantly of northwesetern provenance (Paul 2013: 10-11). On the whole, the EJP is closer to MP than is ENP, and it "may be called an important dialectal link between MP and ENP" (Paul 2013: 11; see also Lazard 1995). There are two analytic Perfects (Paul's "past tenses") in Early Judaeo-Persian formed either with the plain PP rasīd arrive.PP 'arrived' or with the PP in -a rasid $-a$. The copula in the $3^{\text {rd }} \mathrm{Sg}$ is hest. The forms in (32) are "more regular past tenses" while those in (33) "still show an adjectival static character [...] owing to the adjectival origin of the participle" (Paul, pp. 131-135):

nibišt hest 'he has written' (Perfect)

nbyšt bwd [nibišt būd] 'he had written' (Pluperfect)

$\begin{array}{lll}\text { nibišt-a hest } & \text { 'it is written' } & \text { (Perfect) } \\ \text { nbyšt' bwd [nibišt-a būd] } & \text { '(the words) were written' } & \text { (Pluperfect) }\end{array}$

\subsection{Dialectal/ 'Nishapuri' Perfect kard-ast-am 'I have done'}

In Early New Persian poetic and historical texts (written by Attār, BalPami, Beyhaqi, Tabari, and others) there appears another analytic Perfect formation with the $3^{\text {rd }} \mathrm{Sg}$ form of the verb 'to be' /ast/ inserted between the personal suffix and the past base. Some Iranian scholars (Khānlari 1986; Ahmadi Givi 2005) maintain that these forms arose by the attachment of the full forms of the verb 'to be' astan / astidan plus the PP kard. Some scholars consider them to be typical of the dialect of Nishapur (Bahār 1994) or simply dialectal (Khānlari 1986). According to Lazard (1963) and others (Johanson \& Utas 2000; Paul 2008) they are typical of northeastern regions and represent a relic of the Middle Persian 'stand'-Perfect (with the auxiliary ēstādan 'stand') and not 'be'- Perfect (šud èst-am 'I have gone' and šud èstād-ham 'I had gone'). Paul (2013: 134) reports two examples from Early Judaeo-Persian as typical of northeastern New Persian, one of them displaying the form -ist- (kt'b' htmy krdystym [kard-ist-ēm] 'we have sealed the book'). It would seem to us that in other dialectal regions, these forms could have arisen on the basis of the $3^{\text {rd }} \mathrm{Sg}$ form of the 'be'- Perfect kard-ast 'he has done' by adding 
the personal suffixes to it: kard-ast-am, kard-ast-ī, kard-ast-īm, kard-ast-īd, kard-ast-and. In (35) there are some salient examples of these formations (examples from Attār, BalPami and Tabari are quoted after Ahmadi Givi, 2005):

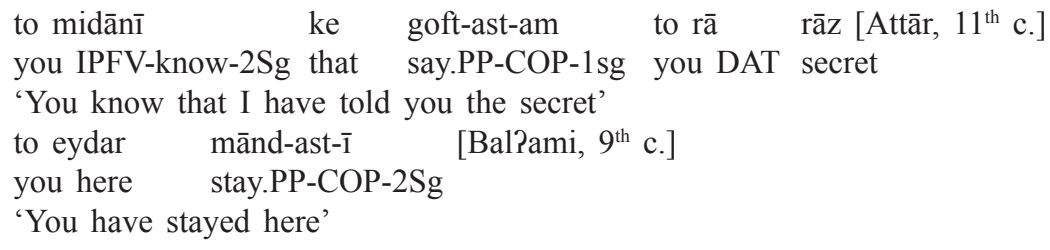

Our perusal of Early New Persian texts reveals instances which seem to be relics of the Middle Persian 'stand'-Perfect. However, upon a closer scrutiny, we suggest that they should be interpreted as examples of the innovative 'be'-Perfect. For instance, har do bistādand [Tafsir-e Tabari, 9 ${ }^{\text {th }}$ c.] 'both of them stood' features the contracted form of èstādan 'stand', be-ēstād-and > bistādand, while barkat kardastīm (in 35) 'we have blessed' is to be interpreted as kard-ast-i do-COP-1Pl (i.e. not as *kard[a]-ist-īm do.PP-stand-1Pl).

In terms of spelling, the same author may use the full form Past and the contracted form ast promiscue; for instance Balkhi (Molavi) $\left[13^{\text {th }} \mathrm{c}.\right]$ spells xedmat-ast 'it is a duty'and Pnayat-?ast 'it is a favor'.

In the case of Past 'he, she is' if the preceding word displays a vocalic coda the contraction also involves the elision of the vowel with only - st remaining: xod $\bar{a}=$ ?ast $>$ xodāst 'God is'. This phenomenon is very common in New Persian and it was also very common in Early New Persian. The following examples are from Tafsir-e Tabari $\left(9^{\text {th }} \mathrm{c}\right.$.):

$$
\begin{aligned}
& \text { haqq-ā ke xodāy e tåālā zudšomār-ast [Tafsir-e Tabari, } 9^{\text {th }} \text { c.] } \\
& \text { right-VOC that God EZ great quick-counting=be-3Sg } \\
& \text { 'It is right that God is quick-counting' }
\end{aligned}
$$

$\begin{array}{lll}\text { goft } & \text { Pesmāil kojā-st, } & \text { goft say.PP } \\ \text { say.PP } & \text { Pesmā?il where=be-3SG } & \text { say. PP } \\ \text { be șeyd } & \text { raft-ast } & \\ \text { to hunting } & \text { go.PP=be-3Sg } & \end{array}$

'He said where is Esmā?il, (s)he said he has gone to hunting'

(37) bad ārāmgāh-ī-st

bad resting place-INDEF $=$ be- $3 \mathrm{Sg}$

'It is a bad resting place'

(35) Is an example of -C Past $>$-Cast, (36) of $-\bar{a}$ Past $>$-āst, (37) of $-\overline{1}$ Past $>-\bar{s}$ st.

The following examples show the contraction of $\bar{e}$ and $\bar{e}$ involving the perfectvizing preverb bē- (followed by $\bar{e}>i$ ) and the verb èstādan/istādan 'stand': 
(38)

har do b-istād-and [Tafsir-e Tabari, ${ }^{\text {th }}$ c.] each two PFV-stand.PP-3Pl

'Both of them stood (up)'
va čun b-istād-i
Pāb b-istād-ī [Hujviri, Kashf ul-mahjub, 12 $2^{\text {th }}$ c.]
and because PFV-stand.PP-PAST water PFV-stand.PP-PAST
'and because it stood, the water stood'

(40) bar sar e rozan-ī b-istād-am [Monshi, Kelile va Demne, $13^{\text {th }}$ c.]

on head EZ opening- INDEF PFV-stand.PP-1Sg

'I stood on [the edge of] an opening'

It stands to reason that if the auxiliary èstādan 'stand' was involved in the formation of the 'long' perfects in Early New Persian one would expect forms such *kard-ist-am, *šod-ist-ī, *būd-ist-1̄ if the auxiliary were ēstād-an 'stand' (as in bēe-estād-and > bistādand). In any case in our perusal of Early New Persian texts we have not come across the forms such as *kard-ist-am, * *̌od-ist-1̄, *būd-ist-1̄.

The remaining issue is whether we are dealing with the fully conjugated verb ast-an 'to be' (so Khānlari and Ahmadi Givi) or with the frozen 'degrammaticalized' form of the copula, ast, to which the personal suffixes were added. We observed the role of the 'frozen' form of the copula, $-a$ (< ast) in the formation of the Perfect in Kurdish in (32): Sorani (Sinayi) wut-ig-m-a say-PP-1Sg-COP 'I have said', Mokri kird- $\bar{u}-t-a$ do-PP-2SgCOP 'you have done', etc.

On the other hand, in Balochi the Pluperfect is formed by inserting the frozen form of the copula, at $(<a s t)$, between the past participle and the personal suffixes: kapt-agat-un fall.PP-COP-1SG 'I had fallen'. This strategy corresponds precisely to the formation of the Pluperfect in Early New Persian:

(41) ma२šuq-am to bud-ast-1 $\quad$ [Molavi, Masnavi $13^{\text {th }} \mathrm{c}$.]

beloved- my you be.PP- COP- $2 \mathrm{Sg}$

'you have been my beloved one'

ke bud-ast-am $\quad$ ze didār $\quad$ e to fard [Divān-e Anvari, $\left.12^{\text {th }} \mathrm{c}.\right]$
that be.PP-COP-1Sg $\quad$ by meeting EZ you solitary
'that I was solitaire by [the lack of] your meeting'

The strategy of using the degrammtiaclized form of the copula as the base for the formation of the perfect base is found in other West Iranian languages (such as Kurdish, Luri and Bakhtiari): The difference consists in the location of the COP which is placed before the personal suffix in Early Modern Persian and Balochi but after the personal suffix in Kurdish and Luri:

$$
\begin{aligned}
& \text { ze dam show tā hālā zāt na-xordo-m-e [Bakhtiāri] } \\
& \text { Since early morning to now food NEG-eat.PP-1Sg-COP } \\
& \text { 'I have not eaten any food since early this morning' }
\end{aligned}
$$


(44)

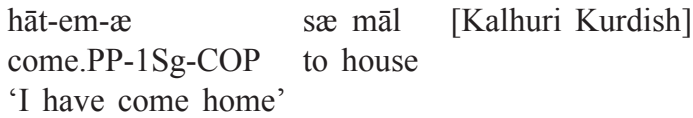

In more general terms, the strategy where the unmarked form of the $3^{\text {rd }} \mathrm{Sg}$ functions as the pivot for the rebuilding of the whole paradigm is covered by Kuryłowicz's second 'law' of analogical extension (1947, as modified by Harris and Campbell 1995:97 ff.). Fairly well-known examples are available from Persian (ast 'is' > (h)ast-am, (h)asti, ...); Polish (jest 'is' > jest-em, jest-eś, ...) and other languages.

\subsection{The analytic Perfect in $-g$ - in Balochi and 'conjectural' mode in Tajik}

As was shown in (31) in Kurdish Sorani (Sinayi) there is a suffix -ig used for the formation of the PP: wut-ig-m- $a$ 'I have said', wut-ig-t-a 'you have said', etc. In Mokri and Sulaymani the PP is formed by $-\bar{u} /-w$ as in kird- $\bar{u}-m-a$ 'I have done', etc. presumably from *kird-ug-m-a (Mokri 2003: 329-335). In Balochi there is a parallel suffix -ag in the same function: kapt-a(g) 'fallen', kurt-a(g) 'done'. The $-g$ - in Balochi is optional but it appears consistently in the formation of the Pluperfect kapt-ag-at-un 'I had fallen' (Jahani \& Korn 2006: 665-666). The Tajik Perfect features $g$-less forms through the whole paradigm of the Perfect but the $-g$ - appears in the formation of the 'conjectural' mood used to express "unsubstantiated conjecture or assumption" (Windfuhr \& Perry 2006: 466). It is a peculiarity of Northern dialects based on the PP in $-a g$ enlarged by $-\bar{l}$ and forms of 'to be'. There are two sets of forms: one formed with the reduced form of the copula $($ ast $>-s t)$ as in [raft-agī]-st 'I suppose he went' or with the copula $-y a m,-y \bar{l}$, y-em, -yed, -yand:

(45) Formation of the Perfect in Sorani (Sinayi), Balochi and the 'conjectural' mode in Tajik

\begin{tabular}{|c|c|c|c|c|}
\hline Balochi & Tajik & 'conjectural' mode & (contracted forms) & \\
\hline kapt-a(g)-un & raft-a am & raftagī-st-am & raftagī-yam & -age/im \\
\hline kapt-a(g)-ay & raft-a $\overline{1}$ & raftagī-st-ī & raftag $\overline{1}-y \overline{1}$ & -agīili \\
\hline kapt-a(g)-Ø & raft-a ast & raftagī-st (zero) & raftagī-st $(<$ ast $)$ & -ag-e $(<\operatorname{as}(\mathrm{t}))$ \\
\hline kapt-a(g)-an & raft-a em & raftagī-st-em & raftagi-yem & -ag-e/im \\
\hline kapt-a(g)-it & raft-a ed & raftagī-st-ed & raftagē-yed & -ag-e/it(on) \\
\hline kapt-a(g)-an & raft-a anc & raftagī-st-and & raftagī-yand & -ag-e/in \\
\hline
\end{tabular}

As it is shown in (45) the reduced form of the copula - st remains constant through the whole paradigm followed by the degrammaticalized form of the copula $-s t(<a s t)$ to which the personal endings are attached: raft-agi-st go+CNJECT-COP 'he may have gone'/'I suppose he went':

(46) $\bar{u}$ az $\quad$ šahr omad-agī-st [Tajik]

he from city come.CNJECT-COP

'he may have come from the city'

The reduction of the person-number inflection and the generalization of the $3 \mathrm{Sg}$ form as an 'impersonal' (subjectless) predicate has been called 'degrammation' (Andersen 2010: 
145). Another example of a degrammaticalized form of the copula -at- (<*ast) appears in the formation of the Balochi Pluperfect which we saw in (31): kapt-ag-at-un fall.PPCOP-1Sg 'I had fallen'. It appears consistently throughout the paradigm (kapt-ag-at-ay 'you had fallen', etc.)

\section{Innovative modal categories: Future, Conditional and Evidential}

\subsection{Future}

In Middle Persian there was no special verbal morphology to refer to events in the future time zone. In New Iranian languages there are considerable differences in this respect. In Sulaimani Kurdish the same present tense form may express not only progressive and habitual activities but also activities in the future time zone: $a-x \bar{o}-m$ IND. eat-1Sg 'I (am) eat(ing), I will eat'(see McCarus 2009: 608). New Persian grammaticalized the lexical verb xāst-an 'to want' in combination with the short infinitive (xâh-am kard 'I will do') for this purpose even though in colloquial Persian - as in Kurdish - the present indicative is used to refer to the future. In Afghan Persian this construction developed 'dubitative' meaning whereby the form of the $3^{\text {rd }} \mathrm{Sg} x \bar{a} h$-ad 'he wants, he will' became the modal auxiliary of probability and in its degrammaticalizeded form can accompany the main verb in any person: zad-a xåt bud-om 'I might hit' (Windfuhr \& Perry 2009: 534). Pashto (East Iranian), on the other hand, exploits its perfective present form for the future time reference (very much as the West and East Slavic languages): ba wá-kr-əm FUT PFV-do.1Sg 'I will do'(Robson \& Tegey 2009: 747).

\subsection{Counterfactual/hypothetical statements}

Instead of the conditional Gathic and Old Persian employ the optative of the Perfect in the apodosis of hypothetical/counterfactual statements (Old Persian ca-xri-ya 'may he have done/if only he had done'; cf. Sanskrit ca-kri-yā-t).

In New Iranian, New Persian uses the indicative forms of the Imperfect in both the protasis and the apodosis to express the fulfillable condition (47), and the past Perfect (Pluperfect) to express the irrealis (wishful thinking) in (48):

(47) agar be man ejāze mi-dādand mi-raftam (Imperfect)

'If they allowed me, I would/should go'

(48) agar gerān na-bud xaride budam (Pluperfect)

'If it had not been expensive, I would/I should have bought it'

(The irrealis can also be expressed by the Imperfect).

Other Iranian languages developed special morphology to express counterfactual/hypothetical statements. Sulaimani Kurdish introduces counterfactuals by the particle $b i$ - in both the present and past Perfect (the following data are from McCarus 2009:b 610-611): 
(49)

$\begin{array}{ll}\text { hāt-uw-a } & \text { 'he has come' } \\ \text { hāt-i bū } & \text { 'he had come' } \\ \text { bi-hāt-ā-y-a } & \text { 'if he had come' (Realis) } \\ \text { bi-hāt-i bw-ā-y-a } & \text { 'if only he had come' (Irrealis) }\end{array}$

The realis is marked by the enclitic $-\bar{a}$ - followed by the degrammaticalized form of the copula. The irrealis combines the reduced form of the PP in $-i\left(<-i_{-}\right)$with the verb 'to be' enlarged by the enclitic $-\bar{a}$ - followed by the degrammaticalized form of the copula $-a(<a s t)$.

In East Iranian, Pashto builds both of its conditionals (introduced by the particle $k a$ ) on the perfect participle in $-a y$ (corresponding to New Persian $-e$ ) which is added to the infinitive in $-a ́ l$ :

$\begin{array}{lll}\text { (50) zə dared-ól-ay yəm } & \text { 'I have stopped' } & \begin{array}{l}\text { Present Perfect } \\ \text { hypothetical }\end{array} \\ \text { ka zə dared-ól-āy } & \text { 'I would stop' } & \\ \text { zə dared-ól-ay vəm } & \text { 'I had stopped' } & \text { Past Perfect } \\ \text { ka zə dared-ól-ay vāy } & \text { 'I would have stopped' } & \text { irrealis }\end{array}$

\subsection{The development of the evidential mode}

The evidential mode is apparently not found in Early New Persian (but there are some contentious instances of 'médiatif' (evidential mode) reported by Lenepveu-Hotz 2012: 230). Modern Standard Persian has a 'subsystem' of evidential forms based on the analytic Perfect rafte ast 'he is gone' (il est parti). This construction is polysemous between the retrospective Perfect rafte-ast 'he is gone' and hearsay or inference 'he is/was said to be gone' or 'I infer that he is/was gone'. Lazard (2001: 361) distinguished between three main uses of the evidential: hearsay, inference and the so-called '(ad)mirative' (known above all from Albanian and other Balkan languages). The diachronic connection between temporal remoteness and retrospectivity of the Perfect and evidentiality was described by Lazard (1989: 272) in the following terms:

"s'est développée par bourgennement à partir d'emplois dérivés du sens de parfait; celui-ci, qui tient à la fois au present et au passé se prête par nature à des évolutions de ce genre".

In New Persian the evidential is available in all the three aspectual categories Imperfective (mi-rafte-ast), Perfective (rafte-ast) and Perfect (rafte bude-ast) and both voices (active and passive). Here is an example of the inferential use of the evidential in the perfective aspect in the passive (quoted after Windfuhr 2009: 461):

$$
\begin{array}{lllll}
\text { mi-guy-and diruz dar yek tasādof dah nafar košte šode-and } \\
\text { IPFV-say.3Pl yesterday in } & \text { one accident ten person } & \text { kill.PP become.PP are } \\
\text { 'They say yesterday ten people got killed in a single accident' }
\end{array}
$$


In the passive evidential the passive auxiliary has to be expressed by the PP šode (become.PP): košte šode-and kill.PP become.PP are 'they allegedly were killed'. If the reporter himself witnessed the accident he would say košte šod-and kill.PP became.3P1 'they were killed' with the passive auxiliary šod-an 'become' in the finite form of the perfective aspect.

Tajik, like Persian, has developed its evidential subsystem in the three aspectual categories and, in addition, it expanded it to include its innovative progressive aspect and modal forms (conjectural mood). (53) is an example of the past progressive inferential (quoted after Windfuhr \& Perry 2010: 464):

$\begin{array}{llllll}\text { vay } & \text { kitob } & \text { xond-a } & \text { istod-a bud-a ast } & \text { [Tajik] } \\ \text { he } & \text { book } & \text { read.PP } & \text { stand.PP } & \text { be.PP is } \\ \text { ki } & \text { man } & \text { dar-ro } & \text { taq taq kard-a am } \\ \text { that I } & \text { door=ACC } & \text { knocking make.PP am } & \text { mored at the door' }\end{array}$

In Tajik the conjectural mode is used to express "an unsubstantiated conjecture or assumption" (Windfuhr \& Perry 2010: 466). It is based on the past participle in -ag (enlarged by $-\vec{l}$ ) followed by the degrammaticalized form of the copula $-s t(<$ ast $)$ to which the personal endings are attached: raft-agi-st go.CNJECT-COP 'he may have gone'/'I suppose he went':

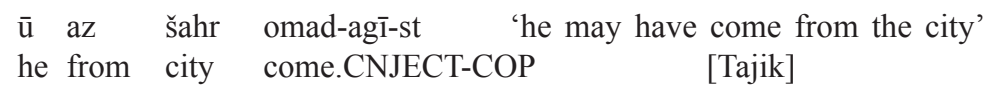

\subsection{Evidential mode in West Iranian languages}

Other West Iranian languages - Kurdish dialects, Luri, Bakhtiari (Anonby \& Asadi 2014), Zazaki (Paul 2009: 561), and apparently Balochi (Jahani \& Korn 2009: 673) "probably under Turkic influence" (Windfuhr 1979, 1982) developed considerably the evidential mode. Consider the following examples of the hearsay usage from Kurdish, Luri and Bakhtiari:

ženaft-em-a Ali čū-a bo širāz [Kurdish, p.c.]

hear.PP-1Sg Ali go.PP-COP to Shiraz

'I heard that Ali has gone to Shiraz'
Ali čū bo širāz
[p.c.]

Ali go.PP to Shiraz

'Ali went to Shiraz [last week]'

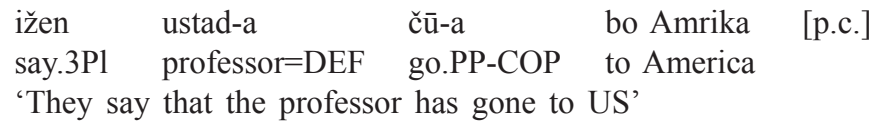


(57)

ešnaft-em-a Ali raft-a wa širāz [Luri, p.c.]

hear.PP-1Sg-be Ali go.PP-COP to Shiraz

'I heard that Ali has gone to Shiraz'

$$
\text { gun ostad rat-a wa Amrika [p.c.] }
$$

say.3Pl professor go.PP-COP to America

They say that the professor has gone to US.

$$
\begin{aligned}
& \text { ašnim red-a } \quad \text { širāz [Bakhtiari, p.c.] } \\
& \text { heard.1Sg go.PP-COP Shiraz } \\
& \text { I heard he has gone to Shiraz }
\end{aligned}
$$

At the end of the continuum of Turkish influence (Windfuhr 1979, 1982) is Tâliši which modeled its evidential mode on the pattern of Turkish inferential $i$-miş (Osmanli $i$-miş) by featuring a single marker ban (adopted from the $3^{\text {rd }} \mathrm{Pl}$ form of the copula). Observe the difference between the inferential based on 'inference' and hear-say in Osmanli:

(60) gel-miş

come.PERF

'I gather that he has come' (inferential)

gel-miş-miş

come.PERF-INF

'I am said that he has come' (hearsay)

\section{Conclusion}

This paper has been written in terms of an interplay of grammaticalization processes as a driving force behind morphosyntactic innovations during consecutive stages in the development of the Iranian family of languges. The intermediate paradigms (Old Iranian participial forms and Middle Persian finite forms) were presented in Tables 2 an 3. The grammaticalization processes of the realignment of the erstwhile possessive/passive construction through the Possessive/Passive-to-Ergative shift was explicated in terms of the restoration of the erstwhile synthetic category of perfectivity by analytic means.

Unlike in Indo-Aryan languages the restoration of inflectional markers in the imperfective aspect by grammaticalized forms of the copula is remarkable. It could be that several of them continue the Old Iranian suffixes (cf. Gathic bar-āmi 'I carry', MP kunam, Parthian kun-ām/-am; Gathic $1^{\text {st }} \mathrm{Pl}$ bar-ämahi, Parthian kun-ām) but most of them are identical with the suffixes of the copula. With the loss of the Old Iranian inflectional Imperfect a number of prefixes/particles started to be used with the PP form to recreate the category of imperfectivity. The crucial event ushering the new state of affairs during the Middle Persian epoch was the grammaticalization of the adverb hamēw 'always' as the imperfectivity marker $(u=m$ hamēw kard and=I+OBL always do $+\mathrm{PP}>\mathrm{New}$ Persian. mi-kardam 'I did' (Imperfect as in French je faisais). Remarkably, various conservative dialects and extinct languages (Sogdian and Khwārezmian) continued the 'ca- 
nonical' way of expressing the imperfective category by combining the present participle with the copula. Another option was adopted in Pashto (East Iranian) which perfectivized the inherited PP by the particle wá- instead of the imperfectivization of the PP in the West Iranian.

The loss of the synthetic mediopassive morphology necessitated the grammaticalization of lexical verbs šut-an 'go' and èstād-an 'stand' as new auxiliaries for the formation of the passive voice. As a result of the incorporation of the PP form kard ( $<*$ kar-ta) into the system of finite forms the former PP form had to be recreated/restored by the grammaticalization of the adjectival suffix $-a k a>-a g>-a>-e$.

The salient innovation in New Persian is the double finite construction of the progressive aspect (not fully paradigmatized): dār-am mi-kon-am 'I am doing', lit. I-hold I-do. This construction is based on the Old Iranian lexical verb $d \bar{a} r$ - (its lexical ancestral meaning is documend in Avestan $d i-\delta \bar{a} r$ - 'grasp' and Old Persian dar- 'hold fast, live in/ at'). However, the same lexical verb was grammaticalized much earlier as an auxiliary of the Perfect in Sogdian and Khwārezmian and it also appears as an auxiliary of the Perfect in contemporary Caspian dialects.

The development of the PP form, further development of the analytic perfect in Kurdish and Balochi, and the development of the analytic perfect in New Persian were outlined and contrasted. The NP form kard-e goes back to kard-a $<$ kard-ag (with an adjectival suffix $-a g)$. The suffix $-a g$ is preserved in Balochi kurt-a(g) 'done', kapt-a(g) fallen' and appears in the Perfect and Pluperfect.

Degrammaticalized forms of the copula were exploited in the formation of more complex aspectual and modal categories. Formation of the Perfect in Kurdish (31) wut-ig-m-a (Sorani) kird- $\bar{u}-m-a$ (Mokri) features addition of the $3^{\text {rd }} \mathrm{Sg}$ ast reduced to the particle $a$ AFTER the personal suffix. On the other hand, in the Balochi Pluperfect (30) the copula is reduced to -at (kapt-ag-at-un) and placed BEFORE the personal suffix.

In Early new Persian with the demise of the Middle Persian 'stand'-Perfect (šud esst$\bar{e} d$ 'he has gone') it became necessary to renew the 'be'-Perfect in its perfect reading by attaching the auxiliary $h$ - 'be' to a plain past base or to a Perfect stem enlarged by $-a$ : kard ast or kard-a ast 'he has done'. The use of the plain PP was gradually discontinued and in the texts composed during the $13^{\text {th }}-14^{\text {th }}$ centuries the Perfect is based on the enlarged PP form kard-a ast (Pluperfect kard-a būd 'he had done'). We paid special attention to another dialectal ('Nishapuri') Perfect formation with the $3^{\text {rd }} \mathrm{Sg}$ form of the verb 'to be' /ast/ inserted between the personal suffix and the past base: kard-ast-am 'do. PP-COP-personal suffix' conjugated by personal suffixes (kard-ast-am 'I have done', kardast $-\bar{l}$ 'you have done', etc.) We examined the issue whether we are dealing with the fully conjugated verb ast-an 'to be' (so Khānlari and Givi) or with the frozen 'degrammaticalized' form of the copula, ast, to which the personal suffixes were added. In this context we re-examined the role of the degrammaticalized ('frozen') form of the copula, $-a$, in the formation of the Perfect located after the personal suffix in Kurdish.

While New Persian uses the indicative forms of the Imperfect and Perfect (Pluperfect) to form its conditional, other Iranian languages developed special morphology to express counterfactual/hypothetical statements (bi- in Sulaimani Kurdish, $k a$ in Pashto). The innovative evidential mode of Modern Standard Persian is based on the analytic Perfect 
rafte ast 'he is gone' and is available in all the three aspectual categories (Imperfective, Perfective and Perfect) and both voices. The evidential mode is developed considerably in other West Iranian languages (Kurdish, Zazaki, Balochi) "probably under Turkic influence" (Windfuhr 1979) but more recently Lazard (2001) emphasized the need to study the issue of the grammaticalization of evidentiality in a larger context of the languages of South Eastern Europe and the Middle East (such as Albanian, Bulgarian, Armenian). Tajik expanded its evidential subsystem to include the innovative progressive aspect and modal forms (to express unsubstantiated conjectures/assumption). In Tajik the conjectural mode is formed by attaching the degrammaticalized form of the copula $-s t(<$ ast $)$ to the past participle in $-a g$ (raftagi-st go.CNJECT-COP 'he may have gone'/'I suppose he went'.

On the whole the Iranian languages possess a wealth of data bearing on the development of their verbal systems during three millennia. Some of the fundamental changes in their alignment and the restructuring of their aspectual systems were taking place between the Late Middle and Early New periods, when the old monolectal categories were restructured as analytic formations. We demonstrated that the degrammation of the copula played a significant role in the formation of compound temporal (Perfect, Pluperfect) and modal categories (Evidential, Conjectural) in New Persian, Kurdish, Balochi and Tajik. Our typological 'subsystem perspective' - focusing on the elaboration and simplification of the intermediate paradigms of the three central aspectual categories - should advance our understanding of the complex history of the Iranian family of languages.

\section{Abbreviations}

EJP - Early Jewish Persian; ENP - Early New Persian; IPFV - imperfective; MP - Middle Persian; NP New Persian; OP - Old Persian; PERF - perfect; PFV - perfective; YA - Yasht Avesta

\section{Editions of primary sources}

Anvari, Awhad ed-Dīn. Divān-e Ash'ār-e Anvari, ed. by Parviz Bābāy (2015). Tehran: Negāh Publications.

Balkhi (Molavi) Muhammad Jalāl ad-Dīn. Kolliyāt-e Shams, ed. by Badiozzamān Foruzānfar (2014). Tehran: Hermes Publishers.

Balkhi (Molavi) Muhammad Jalāl ad-Dīn. Masnavi-ye Ma'navi, ed. by Raynold A. Nicholson (2011). Tehran: Hermes Publications.

Hujwiri, Ali ebn e Osman. Kašf ul-Mahjub, ed. by Mahmud Abedi (2013). Tehran: Sorush Publications.

Jami, Nur ad-Dīn Abd ar-Rahmān. Nafahāt al-Uns men Hazarāt al-Quds, ed. by Mehdi Towhidpur (1996). Tehran: 'elmi Publications.

Monshi, Nasrollah. Kelile va Demne, ed. by Minavi (2014). Tehran: Amir Kabir Publications.

Neyshaburi, Abubakr Atiq. Qesas-e Qor'ān-e Majid, ed. by Yahyā Mahdavi (2013). Tehran: Khwārazmi Publications.

Tabari, Mohammad ibn Jarir. Tarjome-ye Tafsir-e Tabari, ed. by Habib Yaqmāyi (1977). Tehran: Tus Publications.

Bahār, Mohammad Taghi. 2006. Divān-e Ash'ār. Tehran: Negāh Publications.

Kent, Roland. 1953. Old Persian. New Haven, CT: American Oriental Society.

Vahman, Fereydun. 1986. Ardā Wirāz Nāmag. The Iranian 'Divina Commedia'. London, Malmo: Curzon Press. 


\section{References}

Anonby, E. \& Asadi, A. 2014. Bakhtiari; Phonology, text, lexicon. Upsala: Upsala Universitet.

Ahmadi Givi, Hasan. 2005. Dastur-e Zabān-e Färsi. Fe'l [The Grammar of the Persian Language: Verb]. Tehran: Nashr-e Qatreh.

Andersen, Henning. 2010. From morphologization to demorphologization. In Luraghi, Silvia \& Bubenik, Vit (eds.), Companion to Historical Linguistics, 117-146. London, New York: Continuum International Publishing Group.

Baghbidi, Hasan R. 1381. A Grammar of Parthian (Arsacid Pahlavi). Tehran: Iranian Academy of Persian Language and Literature.

Bahār, Mohammad Taghi. 1994. Sabk-shenāsi. Tärix-e Tatavvor-e Nasr-e Färsi [Stylistics: The History of the Evolution of Persian Prose]. Tehran: Amir Kabir Publications.

Durkin-Meisterernst, Desmond. 2009. Khwarezmian. In Windfuhr, Gernot L. (ed.), The Iranian Languages, 336-376. London, New York: Routledge.

Estāji, Azam \& Bubenik, Vit. 2007. On the development of the tense/aspect system in Early and New Persian. Diachronica 24. 31-55.

Gharib, Badrolzamān. 2005. Present and Past Perfect in Sogdian and its similarities to some New Iranian Dialects [translated by Mitrā Faridi]. Guyesh-shenāsi. Tehran: Farhangestān-Zabān va Adab-e Fārsi.

Harris, Alice C. \& Lyle, Campbell. 1995. Historical syntax in cross-linguistic perspective. Cambridge: Cambridge University Press.

Henning, W.B. 1958. Parthisch und Mittelpersisch; das Imperfect. In Hoffmann, K. et al. (eds.), Handbuch der Orientalistik, Vol. 4, Iranistik, 100-104. Leiden: Brill.

Jackson, A. V. W. 1892/1968. An Avesta Grammar in Comparison with Sanskrit. Stuttgart: W. Kohlhammer; repr. Darmstadt: Wissenschaftliche Buchgesellschaft.

Jahani, Carina \& Korn, Agnes. 2009. Balochi. In Windfuhr, Gernot L. (ed.), The Iranian Languages, 634-692. London, New York: Routledge.

Johanson, L. \& Utas, B. 2000. Evidentials: Turkic, Iranian and neighboring languages, Vol. 24. New York, Berlin: Walter de Gruyter.

Joshida, Yutaka. 2009. Sogdian. In Windfuhr, Gernot L. (ed.), The Iranian Languages, 279-335. London, New York: Routledge.

Kalbāsi, Irān. 1995. Tafāvothā-ye vojuh-e fe'li dar Fārsi-ye Tājiki va Fārsi-ye Irān [The Differences in Aspects of Verbs in Iranian Persian and Tajiki Persian]. Majale-ye Dāneshka-ye Adabiyāt o 'olūm-e ensāni. 153 \& 154: 155-170. Tabriz: Dāneshgāh-e Tabriz.

Kalbāsi, Irān. 2004. Gozashte-ye naqli dar lahjehā va guyeshhā-ye Irān [Perfect in dialects and languages of Irān]. Guyesh-shenāsi 2. 66-89.

Khānlari, Perviz. 1986. Tārix-e Zabān-e Fārsi [History of the Persian Language]. Tehran: Nashr-e No.

Lazard, Gilbert. 1963. La langue des plus anciens monuments de la prose persane. Paris.

Lazard, Gilbert. 1995. Le judéo-persan ancien entre le pehlevi et le persan. La formation de la langue persane, 123-131. Paris: Diffusion Peeters.

Lazard, Gilbert. 2001. On the grammaticalization of evidentiality. Journal of Pragmatics 33. 359-367.

Lecoq, Pierre. 1989. Les dialects caspiens et du nord-ouest. In Schmitt, Rüdiger (ed.), Corpus linguarum Iranicarum, 310. Wiesbaden: Reichert Verlag.

Lenepveu-Hotz, Agnes. 2012. Etudes diachronique du système verbal person (Xe-XVIe siècle): d'un équilibre à l'autre? Ecole pratique des hautes études - EPHE PARIS.

Lewis, G. L. 1967. Turkish Grammar. Oxford: Clarendon Press.

Mackenzie, D. N. 1961. Kurdish Dialect Studies, Vol. I-II. London: Oxford University Press.

McCarus, Ernest N. 2009. Kurdish. In Windfuhr, Gernot L. (ed.). 2009. The Iranian Languages, 587-633. London, New York: Routledge.

Mokri, Mohammad. 2003. Grammaire et lexique comparés des dialects kurdes. Paris: Karthala.

Paul, Ludwig. 2009. Zazaki. In Windfuhr, Gernot L. (ed.). 2009. The Iranian Languages, 545-586. London, New York: Routledge.

Paul, Ludwig. 2013. A Grammar of Early Judaeo-Persian. Wiesbaden: Reichert Verlag.

Reichelt, H. 1909/1978. Awestisches Elementarbuch. Heidelberg: Winter.

Robson, Barbara and Tegey, Habibullah. 2009. Pashto. In Windfuhr, Gernot L. (ed.), The Iranian Languages, 721-772. London, New York: Routledge. 
Shafeev, D. A. 1964. A Short Grammatical Outline of Pashto. Bloomington, The Hague [Translated from Russian by H. H. Paper].

Skjärvø, Prods O. 2009. Middle West Iranian. In Windfuhr, Gernot L. (ed.), The Iranian Languages, $196-278$. London, New York: Routledge.

Taheri, E. 2006. The verb in Bakhtiari, Nāme-ye Farhangestān, No2, 86-108. Farhangestān e Zaban: Tehran.

Williams Jackson, A. V. 1968. An Avesta Grammar. Darmstadt: Wissenschaftliche Buchgesellschaft.

Windfuhr, Gernot L. 1979. Persian Grammar. History and State of Research. The Hague: Mouton.

Windfuhr, Gernot L. 1982. The Verbal Category of Inference in Persian. AcIr 22. 263-287.

Windfuhr, Gernot L. 1987. Convergence: Iranian Talyshi and Turkic Azari. In Bashir, E. et al. (eds.), Select papers from Sala 7, South Asian Languages Roundtable Conference, Ann Arbor, Michigan. Bloomington, Indiana: Indiana University Linguistics.

Windfuhr, Gernot L. 2009. Dialectology and topics. In Windfuhr, Gernot L. (ed.), The Iranian Languages, 5-42. London, New York: Routledge.

Windfuhr, Gernot L. (ed.). 2009. The Iranian Languages. London, New York: Routledge.

Windfuhr, Gernot \& Perry, John R. 2009. Persian and Tajik. In Windfuhr, Gernot L. (ed.), The Iranian Languages, 416-544. London, New York: Routledge. 